\title{
Critical Discourse Analysis of the Role of Mass Media in the Cancellation Policy of Hajj Pilgrims during the Pandemic
}

\author{
Rohmanur Aziz ${ }^{*}$ \\ ${ }^{1}$ Universitas Islam Negeri Sunan Gunung Djati, Bandung, Indonesia \\ *ronaz@uinsgd.ac.id
}

\begin{abstract}
This study aims to reveal the role of the media in disseminating information regarding the cancellation of the departure of pilgrims from the critical discourse dimensions. Therefore, this research method uses Critical Discourse Analysis from Norman Fairclough. The results of this study indicate that the role of the media in the cancellation policy of Haijp pilgrims in 2021 consists of three essential things. First, the media sided with the news content about the cancellation of the hajj based on norms by the law and various derivative regulations. Second, the mainstream media group has its concept in understanding how to disseminate the information so that it can become a public discourse and understand the public after being back on the mainstream media stage. Third, the media behaves like a 'pendulum' that can go back and forth to contribute to "orchestrating" the public discourse in this context regarding the cancellation of the departure of the pilgrims.
\end{abstract}

Keywords: Critical discourse; the role of the media; Haij cancellation.

\begin{abstract}
ABSTRAK
Penelitian ini bertujuan untuk mengungkap peranan media dalam menyebarluaskan informasi mengenai pembatalan keberangkatan jamaah haji dilihat dari dimensi-dimensi wacana kritis. Oleh karena itu metode penelitian ini menggunakan Analisis Wacana Kritis dari Norman Fairclough. Hasil penelitian ini menunjukkan bahwa peranan media dalam kebijakan pembatalan jemaah haji tahun 2021 terdiri dari tiga hal penting. Pertama, media berpihak pada konten pemberitaan tentang pembatalan haji berdasarkan pada norma yang sesuai dengan undang-undang dan berbagai peraturan turunannya. Kedua, kelompok media arus utama memiliki konsep tersendiri dalam memahami cara menyebarluaskan informasi sehingga dapat menjadi wacana publik, namun sekaligus dapat memahamkan publik setelah kembali dimainkan di panggung media arus utama. Ketiga, media berperilaku sebagai bandul pendulum yang dapat bolak-balik berkontribusi dalam "mengorkestrakan" wacana publik dalam konteks ini tentang pembatalan pemberangkatan jemaah haji.
\end{abstract}

Kata Kunci: Wacana kritis; peran media; pembatalan haji. 


\section{INTRODUCTION}

Various regulations in the form of legislation are present as a guide for the community in fulfilling their lives. The regulation can be dynamic and open to various possibilities for changes, both planned and unplanned. Planned change is a change made through human engineering consciousness to change one state into another. Meanwhile, unplanned change is change without human control. Like the coronavirus outbreak that resulted in the Corona Virus Disease (Covid 19) pandemic, its emergence has proven to change various conditions without a plan. In this case, globally, there has been a transformation of various conditions concentrated on the attitude towards the Covid 19 issue.

When viewed from the time of change, there are at least two forms of change, namely revolution, and evolution. Revolution is changing quickly, while evolution is the change that takes place slowly or slowly. If we refer to this condition, the Covid 19 pandemic is seen as the cause of the accelerated transformation that changes all aspects of human life and daily activities. This condition gave birth to various new ways in the human interaction process in the world. For example, there are innovative products, ranging from online education systems through e-learning, digital economic systems through e-money facilities, and new ways that accelerate the digitization of human culture.

Social change occurs from the start of changes in people's mindsets, behavior, and cultural materials (Bungin, 2008). The mindset is the structure of the way of thinking influenced by various internal and external factors. Internal factors are innate as a gift of God (fitrah). For example, the capacity of intelligence possessed by humans is innate from birth. In this case, Howard Earl Gardner (1993) refers to multiple intelligences (multiple intelligence).

Gardner tries to criticize the traditional paradigm, which states that human intelligence only relies on the Intellectual Quotient (IQ). That is intelligence that relies on logical, systematic, and mechanistic abilities. Meanwhile, Gardner revealed the postulates of seven essential bits of intelligence, including language and logical-mathematical but also kinesthetic, musical, interpersonal, intrapersonal, and spatial. In other words, human intelligence is not limited to IQ alone but also develops with emotional intelligence (Emotional Quotient) and spiritual intelligence (Spiritual Quotient). 
The Islamic perspective views that every baby is born in a state of fitrah. In this case, internally, humans are equipped with potential by Allah SWT in the form of guidance or instructions in thinking competence ('aql). Thinking is an activity of brain function that is carried out through a series of analyzes and processes that lead to an understanding of knowledge. Externally, the human mindset is influenced by various things related to his existential process. External factors such as environment, past, education level, economic level, and cultural background are seen as having a significant influence in realizing self-identity and social identity. These factors can influence a person's mindset so that it gives birth to perceptions, motivations, and paradigms.

Perception is a quick view of something relative and maybe even superficial. Perception is closer to prejudice, so the truth has not been tested. Conditionally, external factors, such as the environment, have a different impact on urban and rural communities. For example, urban communities perceive COVID-19 as a threat that must be addressed quickly, accurately, and thoughtfully. This is due to the intensity and mobility of urban communities that take place rapidly. Thus, urban communities tend to learn the root causes and anticipatory efforts quickly.

Unlike rural communities, they tend to respond to the emergence of COVID-19 in a different perception. The dominant interactional tendency of rural communities with nature or the environment affects their perception of a situation. If we observe, COVID-19 tends to be taken lightly and is not seen as a severe threat. Therefore, rural communities always try to find justification in responding to various information dissemination about COVID-19. This perception is usually accompanied by the construction of religion and mysticism, which are seen as drugs or powerful weapons in responding to various problems and social dynamics.

The COVID-19 pandemic has changed the daily activities of Indonesian people in various aspects of life. One of them relates to the policy of organizing the pilgrimage. In this case, the impact of the pandemic on the implementation of the Hajj is in the form of a policy of canceling and delaying the departure of Indonesian Hajj pilgrims in 2020 and 2021. Through the Ministry of Religion, the Government of the Republic of Indonesia disseminates information regarding regulations regarding the cancellation of the Hajj. Technically, the Ministry of Religion uses various mass media platforms to disseminate this information.

During the Covid-19 pandemic, the media has a strategic role in 
disseminating information. In this context, the media plays a role in helping to inhibit the spread of the virus during a pandemic by acting as an intermediary in meeting various human needs. In addition, the media conveys information about the pandemic in the process of public communication. In simple terms, the mass media has a role in disseminating information to the public related to various policies for handling the COVID-19 pandemic and its derivative regulations, including those relating to the dissemination of hajj policies.

Sociologically, the role is a dynamic aspect of a position (status). If a person carries out his rights and obligations according to his position, then that person has carried out his role. Position and role are closely related. There is no role without a position. The role determines what things can be done in the community and what opportunities are given to the community. Roles are essential because they can regulate the behavior of others. People who carry out the role will adjust their behavior with those in their group (Soekanto, 2014). Therefore, the mass media's role in disseminating Hajj information is related to the dynamics of organizing Hajj during the pandemic. This role is very strategic, oriented towards building public peace and ensuring the openness and certainty of information.

Hajj is one of the spiritual needs carried out by implementing rituals that are by the conditions, pillars, and obligatory Hajj. However, during the pandemic, in 2020 and 2021, the government views that the departure of the Hajj will endanger the lives of the congregation. Therefore, the government decided to cancel the departure of pilgrims by KMA Number 494 of 2020 and KMA Number 660 of 2021. The phenomenon of canceling the departure of pilgrims during the Covid-19 pandemic is not the first. Historically, similar events have occurred 40 times.

Legally, Law number 08 of 2019 concerning the Organizing of Hajj and Umrah Article 50 paragraph 1c states that:

"Hajj pilgrims whose departure is canceled for valid reasons then in paragraph 3 reads: Hajj pilgrims whose departure is canceled as referred to in paragraph (1) letter c, must receive written notification from the Minister."

This regulation has provided directives for actions that must be taken by the government and the community regarding the Implementation of Hajj and Umrah in an emergency. One of the requirements is to disseminate information and socialize regarding the cancellation of hajj departures. Meanwhile, although the law does not regulate how and 
through what dissemination and socialization of the cancellation of the departure of pilgrims, the media implicitly has a strategic role in this effort.

In conveying information about the cancellation of hajj departures, the government builds power relations with the media to understand the community and anticipate protests and lawsuits that the community may make to the government. According to Levinson, in this position, the media has a role bound by norms, concepts, and behavior. The role itself is used as a pattern of attitudes, behavior, values, and goals expected from a particular subject based on his position in society. At the same time, the role shows the subject of a particular person or group.

"Roles cannot be separated from roles because if an official or group or even an individual has performed his or her role according to agreed norms, then an official or leader has been declared to play a role in the group" (Informant).

The role of the media is related to communication systems and devices in the form of software (software), hardware (hardware), ideas (brainwave), users, symbols, networking, and ideology. The emergence of the media has a significant impact on daily human activities. The development of mass media is not only related to print or electronic media. Another development is marked by the emergence of new media such as the internet. In the process, new media such as the internet gave rise to communication tools that were carried out in new ways. These interactional ways are done, for example, through social media.

The term social media is composed of two words, namely "media" and "social." "Media" is defined as a communication tool (Laughey, 2007; McQuail, 2003). In comparison, the word "social" is defined as a social fact that every individual takes actions that contribute to society. This statement confirms that, in reality, media and all software are products of social processes (Durkheim in Fuchs, 2014; Mulawarman \& Nurfitri, 2017). In other words, communication systems and devices are an integral part of human culture that are used to fulfill human sociological needs.

Communication and da'wah by using the cyber world are seen as being able to smoothen the barriers of space and time. Where geographical barriers are no longer an obstacle. The development of communication technology is a breath of fresh air for the dynamics of da'wah. Of course, this has encouraged practitioners and experts of da'wah to get to know and be closer to technology (Rustandi, 2019; Kusnawan \& Rustandi: 2021). Among the da'wah practitioners are religious instructors who take 
advantage of this opportunity by using the internet as a medium of da'wah. In this case, the process of using internet media must be accompanied by the level of digital literacy, both in terms of skills, culture, ethics, and security in its use.

Communication technology is defined as a system of activities or forces of two or more people, which are consciously coordinated (Barnard, 1938). The development of information and communication technology offers a new way of interacting with life. The term e-life or digital life is becoming familiar among humans, reflecting the opportunities and challenges in using technology for daily human activities. Various public activities are conducted virtually with new media and methods, such as e-commerce, egovernment, e-education, e-learning, e-library, e-journal, e-medicine, elaboratory, e-da'wah, and others. This digitalization of human culture occurs at the individual, communal and institutional levels (Fakhruroji, Rustandi \& Busro, 2020).

Information and communication technology like this has a significant impact on the implementation of Islamic da'wah activities. Therefore, the da'wah revolution can be seen from the trend in technological devices such as mobile phones or smartphones, internet connections, applications, and social media as a medium for disseminating Islamic messages. The da'wah science perspective calls this model called the da'wah al-kahruba'i, a new da'wah model due to the global and digital era (Sambas, 2009).

Da'wah is a theological and sociological obligation for every human being. His professional background carries out this obligation. Da'wah activity can be said as a multidimensional activity. Islamic da'wah activities are not only carried out with bi al-lisan, but also with bi al-Kitab (by writing), bi at-tadbir (management/organization), and bi al-hal (social action). A good preacher not only masters da'wah material but also has to understand the culture of the community that is the target of his da'wah. This will make it easier for the preacher to choose the media and determine the method of preaching that is by the needs and conditions of his honey.

The technological revolution with the invention of communication devices such as LPs, cassettes, CDs, DVDs, and flash drives has brought significant changes in terms of data storage. These devices are not only used for entertainment activities, such as music recording and cinematography. However, they are also used to disseminate da'wah messages. So that $\mathrm{mad}^{\prime} u$ can use it as a learning medium anytime and repeatedly. 
At this time, information technology is available, making it easier for us to interact with the internet. The discovery of social networking sites such as Facebook created by Mark Zuckerberg on September 11, 2006, or Twitter by Jack Dorsey, Biz Stone, \& Evan Williams in March 2006, even Google Buz February 9, 2010, created by the Google team has made it easier for people to communicate and form communities. In the virtual world. This media interaction process is carried out in various community interests, including in da'wah activities and the implementation of the pilgrimage.

As explained by Linden Research, who introduced a new service called "Pulau Haji'. This service is aimed at every Muslim who may not have had the opportunity to perform Hajj. In addition, this virtual pilgrimage can also be used for hajj da'wah while reducing common mistakes often made by many pilgrims. "Hajj Island" technology depicts the city of Mecca in a three-dimensional way. Visitors can see the Kaaba, the hills of Safa and Marwah, and visit Mina.

Through this website, many Muslim and non-Muslim visitors come to attend lectures and training about Hajj. The service is available free of charge, along with an English and Arabic introduction. About 400 people visit the "Island of Hajj" per day.

Awatef Mohammad Fahim, head of the Development Team of Second Life, said the virtual Hajj training took about 45 minutes. After logging in, the trainee, in the form of a three-dimensional character (called an avatar), wanders through a virtual world that includes all Hajj locations and holy places. Fahim revealed that the program begins with avatars who are already wearing the ritual robes of Hajj or Ihram. After wearing ihram, the avatar is free to move around the Grand Mosque in Mecca and perform worship according to the pillars of Hajj.

He explained that while on the island of Hajj, users still get information in the form of signs, numbers, arrows, maps, and pictures. In addition, the "Island of Hajj" can also learn the prayers needed during the Hajj. Another purpose of the hajj island is to introduce non-Muslim communities to Islam. Of the 25 million registered people in Second Life, most of them are non-Muslims. The mixing of Muslims and non-Muslims here allows non-Muslims the opportunity to learn more about Islam. Many women from America, Britain, and Europe participated in the training program.

The 'Hajj Island' phenomenon as an application-based virtual Hajj 
service in the second life shows a new way of training Hajj rituals. Transforming technological adaptation in the Hajj rituals implementation is an exciting phenomenon that is important to study, especially during a pandemic. This reinforces the assumption that digital technology affects human interactional structures in various ways. This influence process can be seen from the widespread use of internet media as a new interaction platform.

Several researchers have carried out research related to the policy of canceling the pilgrimage. For example, the study of Saputera and Putra (2020) reviews Islamic law regarding the problems of Hajj investment during the pandemic. The study results stated that the use of hajj funds for infrastructure development through investment during the covid-19 outbreak was maslahah as long as it did not violate the provisions of the Shari'a by committing immorality in the form of usury, gharar, maysir, and tadlis. This research was strengthened by Junaedi, Arsyad, and Aurijah (2021) regarding the optimization of the Hajj fund investment in the pandemic era. It is concluded that gold investment, sharia stock investment, and rice agribusiness investment can be a priority choices for Hajj financial investment.

Alfiyah and Isa (2020) researched aspects of the pilgrimage. They examined the strategy of tour and travel bureau companies in organizing Hajj during the pandemic. The study results indicate that managerial strategies, providing motivation, and strengthening information about regulations are the main strategies that can be applied to implement the Hajj journey during the pandemic.

This study aims to analyze the dissemination of information related to the Hajj cancellation policy during the COVID-19 pandemic. This is primarily directed at exploring power and media relations, focusing on the role of the mass media in disseminating policy information. Research that takes the point of view of the role of the mass media in responding to the hajj cancellation policy is still minimal, even if it does not exist. Therefore, this research has a novel value relevant to the objective conditions of the implementation of the Hajj during the pandemic. This study explores the phenomenon by analyzing media texts about the news of the cancellation of the hajj pilgrimage in 2020 and 2021.

The research was conducted with a qualitative approach that seeks to explore data in words (Moleong, 1993). The method used in this research is the Critical Discourse Analysis from Norman Fairclough. According to 
him, there are three dimensions in Critical Discourse Analysis. First, the textual (microstructural) dimension consists of representation, relation, and identity when viewed from its function. Representation is a description of social reality (Rustandi, 2018).

In the context of the cancellation of the hajj, there is a commotion. The relationship is meant as a pattern of relations between religious, political, and legal issues. The three identities are the characteristics of the media that play their function as messengers. Second, the discursive dimension of social cognition (meso-structural), namely various dynamics related to text production, text distribution, and text consumption, becomes a discourse on social media. Third, the dimension of social practice through social cognition (macro-structural), namely the dimension that describes the various influences and impacts on situational, institutional and social (Fairclaough, 1941).

\section{RESULT AND DISCUSSION}

\section{Media Dissemination Cancellation of Hajj Pilgrimage}

Law number 8 of 2019 concerning the Organization of Hajj and Umrah is a product of the legislation of the House of Representatives of the Republic of Indonesia (DPR RI) as a form of the state's presence in managing the Islamic community in Indonesia before, during, and after performing the pilgrimage. Two main points are used as the purpose of the law as stated in article 3, namely, first, to provide guidance, service, and protection for the Hajj and Umrah pilgrims so that they can perform their worship according to the demands of the Shari'ah, and second, realizing independence and resilience in the Organization of Hajj and Umrah. These two goals apply during normal and abnormal times, such as during the Coronaviruses Diseases (Covid-19) pandemic, because the state focuses on protecting the community with various policies that favor the community.

In 2020, there has been a fundamental policy for prospective pilgrims with the closure of the cities of Mecca and Medina by the Saudi Arabian government as a response and protection effort during the Covid-19 pandemic. Therefore, through the Ministry of Religion of the Republic of Indonesia, the Indonesian government automatically cancels the departure of pilgrims as stipulated in Law number 8 of 2019, which is contained in article 50 .

Thus, the DPR proactively disseminates and socializes the 
cancellation of the departure of pilgrims due to apparent reasons. Force, namely the Covid-19 Pandemic. The synergistic collaboration between the Ministry of Religion of the Republic of Indonesia, in this case, the Regional Office of the Ministry of Religion of West Java Province with members of the House of Representatives from Commission VIII, which includes the management of the Hajj and Umrah services, is generally considered good.

The media used for this dissemination are conventional media such as stage, pulpit, sound system, projector, digital camera, and backdrop. This was done because the dissemination process was carried out offline by members of Commission VIII of the DPR RI. The participants of the dissemination were community leaders and representatives of the Hajj and Umrah Guidance Group (KBIHU).

The contents of the dissemination are in the form of regulations regarding Hajj and Umrah. Hajj regulations are all regulations that regulate various series of activities in carrying out the pilgrimage. According to law number 13 of 2008 article 1 paragraph (2), the implementation of the pilgrimage is a series of activities for the implementation of the pilgrimage, which includes the development, service, and protection of pilgrims.

Legislation number 8 of 2019 concerning the implementation of Hajj and Umrah. It deals with general provisions for organizing, organizing, guiding groups, the principles of Hajj and Umrah, citizens, rights and obligations of pilgrims, hajj quotas, proportions, and other provisions.

Historically, the history of the pilgrimage in Indonesia has been treated by various laws and regulations, which were heavily influenced by the socio-political conditions of the time. Since the colonial period, the implementation of the hajj pilgrimage has been based on Dutch regulations, namely the pilgrim's ordonnance staatblaads 1922 number 698 including changes and additions and the pilgrims verordening in 1938.

During the New Order era, the two regulations had not been revoked. However, they were supplemented with other regulations in the form of regulations/decrees of the President of the Republic of Indonesia, including Presidential Decree No. 3 of 1960 concerning the implementation of hajj affairs, the Presidential Regulation of the Republic of Indonesia No. 112 of 1964 concerning the implementation of interdepartmental hajj affairs, Presidential Decree No. 22 of 1969 concerning the administration of Hajj affairs by the government, Presidential Decree No. 53 of 1981 concerning the implementation of hajj affairs, and the Presidential Decree of the Republic of Indonesia No. 62 of 
1995 concerning the implementation of the Hajj. Change after the change is made to implement a good pilgrimage and achieve a certain satisfaction for the pilgrims. It is necessary to have a foundation as an instrument in implementing the pilgrimage, namely the existence of the principles and objectives of organizing the pilgrimage.

Government Policy After the issuance of PMA 494 in 2020, Hajj Pilgrims in 2021, Regular Hajj, and Special Hajj congregations that have been paid off automatically become delayed paid congregations who will depart the following year. The value of the BIPIH payment deposit benefits will be given by BPKH to the Haji pilgrims no later than 30 days before the departure of the first batch of Hajj pilgrims in $1442 \mathrm{H} / 2021$ AD. The KBIHU \& PHD Supervisors in 1441 H / 2020 M are declared canceled, $\mathrm{BIPIH}$ is returned, and the KBIHU/Governor can propose back to Hajj in $1442 \mathrm{H} / 2021 \mathrm{AD}$. Congregational health checks at the Hajj 1442 $\mathrm{H} / 2021 \mathrm{AD}$ are by the policy of the Ministry of Health. Identity bracelets, Manasik books, BPS souvenirs, and equipment for Hajj Officers for the Year $1441 \mathrm{H} / 2020 \mathrm{M}$ will be used for Hajj departures in $1442 \mathrm{H} / 2021 \mathrm{M}$.

The government, PIHK, and KBIHU guide Hajj rituals to the Regular Hajj Pilgrims during the Hajj Pilgrimage Year 1442 H/2021M. Airlines that have been designated as air transportation providers in 1441 $\mathrm{H} / 2020 \mathrm{M}$ will be re-assigned as air transportation providers in the Organization of the Hajj in 1442H/2021M. Service providers in the Hajj Dormitory established in the Year 1441 H/2020 AD will be re-assigned as a service provider in the Hajj Dormitory in the Organization of the Hajj in $1442 \mathrm{H} / 2021$ AD. Service providers in Saudi Arabia, established in the Year $1441 \mathrm{H} / 2020 \mathrm{M}$, will be re-assigned as a service provider in Saudi Arabia in the Organization of the Hajj in 1442 H/2021 AD. The results of the selection of PPIH Kloter and Saudi Arabia in 1441 H/2020 M become the basis for determining the PPIH Kloter and Saudi Arabia in the Organization of the Hajj in $1442 \mathrm{H} / 2021 \mathrm{M}$.

The various regulations above show the Indonesian Government's efforts in responding to the COVID-19 pandemic in organizing the pilgrimage. Of course, the regulations issued do not only consider the socio-political aspects that impact the Hajj pilgrims and their various implementation efforts - but also viewed from the point of view of Islamic teachings, which provide leeway as to the basis of the Shari'a in making these policies. The fiqh review concludes that when a sense of security is not fulfilled, regardless of the factors including the coronavirus, both on 
the route to Mecca and in Mecca itself, Hajj is not obligatory to carry out, including in conditions of the covid-19 pandemic (Nur, 2020).

The Government of Indonesia periodically disseminates the regulation through the Ministry of Religion. Dissemination is the process of interaction in communicating knowledge to the target audience to be used to lead to change. Dissemination is influenced by five interrelated things, namely source (communicator), content (message), context (context), medium (media), and user (receiver) (Fatkhah, Winoto \& Khadijah, 2015; Ordonez, 2017). In this case, the communicator is the Government of Indonesia through the Ministry of Religion. The message conveyed is the policy of canceling the Hajj in 2020 and 2021. The developing context is related to the response to the COVID-19 pandemic. The media used are varied in the form of conventional media and mass media. The users of this message, in particular, are the Hajj pilgrims and organizers and the Indonesian people in general.

Media has a function in the message distribution process. In this case, information dissemination through certain media will have implications for the audience both in terms of frames of reference and field of experience (Gerry, Roem \& Dewi, 2018). The choice of media in the dissemination of information will determine the reach and effectiveness of message dissemination. In this case, communication events are oriented towards forming the same meaning between the sender and the receiver. Therefore, the communication message conveyed should pay attention to the condition of the communicant both in terms of thoughts, feelings, and experiences (Rustandi, 2020). In this case, the dissemination of information leads to an influence on mentality and action. Mental events in communication are related to the internal mediation of stimuli as a result of ongoing communication. Behavioral events are what appear when people communicate (Rahmat, 2007: 7-9).

The use of conventional media at the beginning of the dissemination of information on Hajj cancellation policies has implications for the level of public acceptance. So that in the end, information dissemination also uses digital media such as social media. In this case, the government as a communicator needs to pay attention to the context of the message delivered, both related to mental and behavioral events. This can be seen from the variety of public comments after the dissemination of this information. Not to mention the follow-up policies related to the conversion and investment of Hajj funds that are used for other purposes. 
Of course, the scope of the communication context to disseminate information related to the Hajj cancellation policy has implications for the mental context and actions of the audience.

The information dissemination process leads to the similarity of the meaning of communication in the form of perceptual and interactional contacts (Perdana \& Kusuma, 2019: 256). Both show a process of mutual adaptation and map the conditions of communication that take place both perceptually and interactively (Liliweri, 1994). In this case, information dissemination maps the process of message ideation, receiving messages, sending messages, and the personal and situational factors that influence them (Yanti, 2019: 250). Therefore, the selection of media in disseminating information on the cancellation of $\mathrm{Hajj}$ is an essential factor in implementing public communication. So that in the end, there is a similarity of meaning both perceptually and interactively between the organizers and the pilgrims. This similarity of meaning will affect the mentality and actions of the public as users in this communication event.

\section{The Role of Media in Cancellation of Departure for Hajj Pilgrims}

The cancellation of the departure of the Hajj pilgrims in 2020, as stated in the Minister of Religion Decree number 494, seems to be free from criticism and is relatively accepted by the public. This is due to the political upheaval that the elites talk about, such as in online news headlines. This is suspected to be due to the limited political communication between the government and the DPR, especially Commission VIII, in charge of religion and social affairs, including those related to the implementation of the pilgrimage. The limitation of political communication in the determination of KMA 494 is more because the adaptation period to the pandemic has significant implications for public activities, both daily and related to aspects of state policy.

Figure 1. One of the online media headlines regarding the cancellation of the departure of the pilgrims

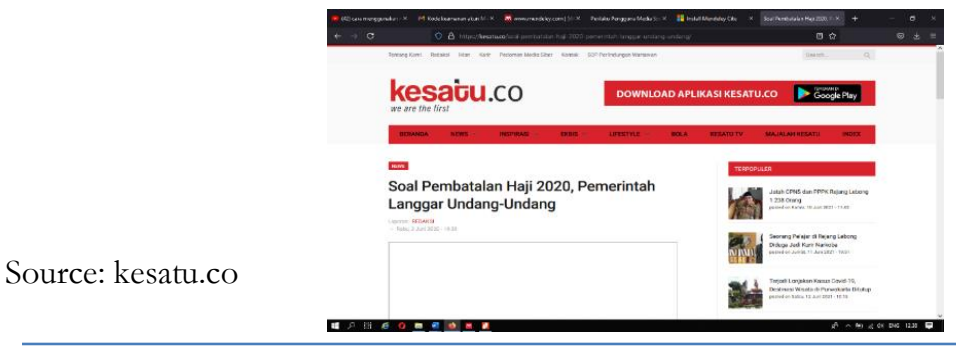

Ilmu Dakwah: Academic Joumal for Homiletic Studies 15(1) (2021) 127-148 
Figure 1 above shows a headline from one of Indonesia's online media that reported the cancellation of the Hajj in 2020. This news highlights the regulations that are the basis for canceling the Hajj during the pandemic. Therefore, textually and contextually, the discourse on news coverage in the media above leads to exploring the basic policies of Hajj. In this case, the dissemination of information focuses on extracting arguments as a response to canceling the pilgrimage. However, efforts to criticize the 2020 Hajj cancellation policy do not dominate the public news spaces.

This is different in 2021 after the government canceled the departure of pilgrims through the Decree of the Minister of Religion number 660 of 2021 by considering the safety of the congregation's souls by the maqashid shari'ah contained in the KMA considerations. The government elite and the DPR appear to be compact and harmonious. However, there is a commotion in the public sphere both on social media and in mainstream media, as shown in Figure 2 below.

Figure 2. Compass Reporting. Com about Hajj Cancellation the year 2021

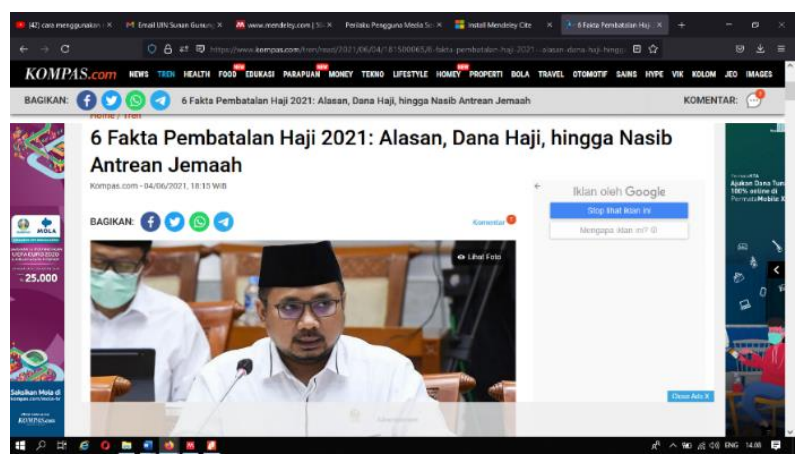

Source: kompas.com

Figure 2 shows a photo of the 2020 and 2021 Hajj cancellation press conferences. The government invited various mass media owners, both electronic and print. However, something interesting appears on the surface, namely the absence of TVRI as a state-owned broadcasting institution. Present at the live event were two private television stations, namely TV One and Metro TV. These two private television stations have been known as antagonistic media since the 2017 DKI Jakarta Regional Head Election until the 2019 Presidential Election. In this position, these 
two electronic media occupy the 1 st level of role in disseminating information. Both of them were present at a press conference on June 3, 2021, when the Indonesian Minister of Religion Yaqut Cholil Qoumas announced the cancellation of the departure of the Hajj pilgrims in 2021.

At level 2, online news quickly disseminates information across all online media platforms. In this case, online media continues the narrative and discourse that develops throughout social media platforms as the 3rd level media. At the third level, there was a discourse controversy about the public's attitude towards the government's announcement of the cancellation of the Hajj pilgrims in 2021. Some refused and questioned the government's attitude and even accused the government of being unprepared to carry out the pilgrimage, including those busy talking about using the Hajj deposit funds from the public, which the government manages. Others include understanding that the main reason for canceling the pilgrimage in 2021 is pandemic reasons that can endanger the lives of pilgrims.

There are three views of language in discourse analysis (Fairclaough, 1941). The first view is represented by the positivist-empirical. By these people, language is seen as a bridge between humans and objects outside themselves. Human experiences are considered to be directly expressed through language without any obstacles or distortions, as long as they are expressed using logical, syntactical statements and have a relationship with practical experience. One of the characteristics of this thinking is the separation between thought and reality.

About discourse analysis, the logical consequence of this understanding is that people do not need to know the subjective meanings or values that underlie the statement because what is important is whether the statement is made correctly according to syntactic and semantic rules (Meyrowitz, 2007). Therefore, the grammar of syntactic truth is the central area of the positivist-empirical school of discourse. Discourse analysis is intended to describe the arrangement of sentence rules, language, and shared understanding. Discourse is then measured by considering truth/untruth (according to syntax and semantics). This flow belongs to the group supporting the government's policy of canceling the hajj in 2020 and 2021 due to the pandemic.

The second view is referred to as constructivism. This view is heavily influenced by phenomenological thinking. This school rejects the view of empiricism/positivism that separates the subject and object of language. In 
the view of constructivism, language is no longer seen only as a tool to understand objective reality alone and separated from the subject as a conveyer of statements. Constructivism considers the subject a central factor in discourse activities and social relations (Akhmad \& Ibrahim, 2014). In this case, the subject can control particular intentions in each discourse. Language understood in this paradigm is governed and brought to life by purposeful statements (Hikam, 1996).

Every statement is an act of creating meaning, that is, an act of selfformation and self-disclosure of the speaker. The discourse analysis of the group who questioned the cancellation of the pilgrimage was intended as an analysis to uncover specific intentions and meanings. The discourse on various social media platforms about the controversy over the cancellation of the Hajj is an attempt to reveal the hidden intentions of the government as the subject making a statement. The disclosure is done, among others, by placing oneself in the speaker's position with interpretation following the structure of the meaning of the speaker.

The third view is called the critical view. This view aims to correct the constructivism view, which is less sensitive to the process of production and reproduction of meaning that occurs historically and institutionally. The constructivist view has not analyzed the power relations factors inherent in every discourse, which play a role in shaping certain types of subjects and their behaviors. This is what gave birth to the critical paradigm. Discourse analysis is not centered on the truth/untruth of grammatical structures or interpretive processes as in constructivism analysis (Hikam, 1996).

The third group analysis in assessing the cancellation of the $2021 \mathrm{Hajj}$ in this paradigm emphasizes the constellation of forces that occur in the production and reproduction of meaning. Individuals are not considered neutral subjects who can interpret freely according to their thoughts because they are closely related and influenced by social forces that exist in society. The language here is not understood as a neutral medium that lies outside of the speaker or writer. In a critical view, language is understood as a representation that plays a role in shaping certain subjects, specific discourse themes, and strategies (Akhmad \& Ibrahim, 2014).

Therefore, this third group analysis is used to uncover the power in each language process, which is related to the boundaries of what is allowed to become discourse, the perspective that must be used, and what topics are discussed. With this kind of view, discourse sees that language is always 
involved in power relations, especially in the formation of subjects and various representational actions contained in society. This third paradigm is represented by critical groups in the media circle with various presentations that want to be discussed to attract public attention informing the media as a new subject in the policy of canceling pilgrims.

In the perspective of Norman Fairclough's Critical Discourse Analysis (1941), the cancellation of the departure of the Hajj pilgrims in 2021 can be seen in three dimensions. First, microstructurally on the textual dimension. This dimension can be seen from the statement of the announcement of the cancellation of the departure of the pilgrims by the Minister of Religion representing the government supported by government relations, namely the DPR RI, as partners and supervisors for implementing the law. This also shows the government's identity as the holder of power and the party most responsible for the Hajj issue.

Second, the mesostructure dimension, namely the social cognition of the community in responding to the announcement of the cancellation of the 2021 Hajj departure, involves level 1 media, namely electronic media represented by TV One and Metro TV. Then it spreads to online and print media as level 2 media and then becomes social media discourse as information that is considered controversial, which is crowded on social media as level 3 .

In the third dimension, it appears that the Ministry of Religion is compactly immediately forwarding information on the cancellation of Hajj to Regional Offices throughout the province and followed by socialization actions to the Ministry of Religion of the Regency/City and in collaboration with the Hajj and Umrah Worship Guidance Groups until the information on the cancellation of the departure of Hajj pilgrims penetrates to all candidates. Hajj pilgrims throughout Indonesia. However, it was recorded that until June 14, 2021, 127 prospective hajj pilgrims submitted a withdrawal of the payment deposit.

Critically, the three dimensions describe how the ideation, distribution, acceptance, and audience response in accepting the discourse of canceling the pilgrimage (Yanti, 2019). In the context of communication, the process of ideation, dissemination, and acceptance of messages has implications for the meaning of messages. In this case, the media becomes a space that produces and distributes communication messages, thereby strengthening the frame of reference and field of experience between communicators and communicants (Effendy, 2003). Therefore, the 
Indonesian government's dissemination of information related to this by using television mass media at the first level, print and online media at the second level, and social media at the third level. These three media critically construct communication messages both on microstructural, mesostructure, and macrostructural aspects.

\section{CONCLUSION}

The role of the media in the policy of canceling Hajj pilgrims in 2021 consists of three essential things. First, the media sided with the news content about the cancellation of the hajj based on norms by the law and various derivative regulations. Second, the mainstream media group has its concept in understanding how to disseminate the information so that it can become a public discourse and understand the public after being back on the mainstream media stage. Third, the media behaves like a pendulum that can go back and forth to contribute to "orchestrating" public discourse, in this context, regarding the cancellation of the departure of pilgrims.

According to the perspective of Critical Discourse Analysis, microstructurally on the textual dimension, the announcement of the cancellation of the departure of pilgrims by the Minister of Religion represents the government. On the mesostructure dimension, the announcement of the cancellation of the 2021 hajj departures involving mainstream media continued to social media. As for the action dimension, the Ministry of Religion is considered successful in disseminating information on the cancellation of the departure of pilgrims to all prospective pilgrims throughout Indonesia.

\section{REFERENCES}

Akhmad, B. A., \& Ibrahim, I. S (2014). Komunikasi dan Komodifikasi; Mengkaji Media dan Budaya dalam Dinamika Globalisasi. Jakarta: Yayasan Pustaka Obor Indonesia.

Alfiyah, L., \& Isa, W. (2020). Strategi Adaptasi Perusahaan Biro Tour and Travel Dalam Menghadapi Pandemi Covid-19 (Studi Kasus Pada Perusahaan Tour and Travel Haji dan Umrah PT. Amanu Izzah Zamzam Sakinah di Kota Surakarta), Akademika: Jumal Keagamaan dan Pendidikan, 16(2), 113-127. https://ejournal.kampusmelayu.ac.id/index.php/akademika/article /view/122/126. 
Barnard, C. (1938). The Functions of the Executive. Cambridge, MA: Harvard University Press.

Bungin, B. (2008). Sosiologi Komunikasi. Jakarta: Kencana Prenada.

Departemen Agama RI. Direktorat Jenderal Bimbingan Masyarakat Islam dan Penyelenggaraan Haji, Petunjuk Teknis Pengorganisasian Kelompok Bimbingan Ibadah H (Ri, 2003) (Kebudayaan, 1995) (KBIH). (Jakarta, 2004).

Direktoran jendral penyelenggaraan haji dan Umrah, Fiqh Haji Komprehensif. (2015). Jakarta: Kementrian Agama RI.

Effendy, O. U. (2003). Ilmu, Teori, dan Filsafat Komunikasi. Bandung: PT. Citra Aditya Bakti.

Fairclaough, N. (1941). Language and Power, British Library Cataloguing in Publication Data.

Fakhruroji, M., Rustandi, R., \& Busro. (2020). Bahasa Agama di Media Sosial: Analisis Framing pada Media Sosial Islam Populer, Jurnal Bimas Islam, 13(2), 203-234. https://doi.org/10.37302/jbi.v13i2.294.

Fatkhah, U., Winoto, Y., \& Khadijah, U. L. S. (2020). Diseminasi informasi zero waste oleh Yayasan Pengembangan Biosains dan Bioteknologi. Jurnal Kajian Informasi \& Perpustakaan, 8(1), 49-68. https://doi.org/10.24198/jkip.v8i1.26615.

Gardner, H. (1993). Multiple Intelligence: The Teory in Practice a Reader. USA: Basic Book.

Gerry., Roem, E. R., \& Dewi, R. S. (2018). Model Diseminasi Informasi Pemerintah Kota Padang melalui Media Siber, JRK: Jurnal Ranah Komunikasi, 2(2), 81-88. DOI: https://doi.org/10.25077/rk.2.2.8188.2018.

Hikam, M. A. S. (1996). Bahasa dan Politik: Penghampiran Discursive Practice. Jakarta: LP3S.

Junaedi, D., Arsyad, M. R., \& Aurijah, S. C. (2021). Optimalidasi Investasi Dana Haji Era Pandemi Covid-19, Al-Kharaj: Jurnal Ekonomi, Keuangan \& Bisnis Syariah, 3(1), 1-16. https://doi.org/10.47467/alkharaj.v3i1.150.

Kusnawan, A., \& Rustandi, R. (2021). Menemukan Moderasi Beragama dalam Kaderisasi Dakwah: Kajian pada Pemuda Persatuan Islam Jawa Barat, Nalar: Jurnal Peradaban dan Pemikiran Islam, 5(1), 41-61. DOI: 10.23971/njppi.v5i1.2900.

Laughey, D. (2007). Themes in media theory. New York: Open University Press. 
Liliweri, A. (1994). Perspektif Teoritis Komunikasi Antarpribadi. Bandung : PT Citra Aditya Bhakti.

McQuail, D. (2003). Teori komunikasi massa. Jakarta: Penerbit Erlangga.

Meyrowitz, J. (2007). Media/Theory; Thinking About Media and Communications.

Moleong, L. J. (1993). Metode Penelitian Kualitatif, Bandung: Remaja Rosdakarya.

Mulawarman., \& Nurfitri, A. D. (2017). Perilaku Pengguna Media Sosial beserta Implikasinya Ditinjau dari Perspektif Psikologi Sosial Terapan, Buletin Psikologi, 25(1), 36-44. DOI: 10.22146/buletinpsikologi.22759.

Nur, S. (2020). Pelaksanaan Ibadah Haji Pada Masa Pandemi Covid 19; Studi Komparatif Perspektif Mazhab Fikih, Mazabibuna: Jurnal Perbandingan Marhab, 2(2), 134-150. DOI: https://doi.org/10.24252/mh.v2i2.15075.

Ordonez, M. \&. (2017). Disseminating Knowledge Products. Knowledge Solution, 871-878.

Perdana, F. P., \& Kusuma, R. S. (2019). Komunikasi Interpersonal Pada Komunitas Dakwah Binaan Nusukan Dari MTA Dalam Membentuk Ukhuwah, KOMUNIKA: Jurnal Dakwah dan Komunikasi, 13(2), 249264. DOI: https://doi.org/10.24090/komunika.v13i2.2750.

Rahmat, J. (2007). Psikologi Komunikasi. Bandung : PT Remaja Rosdakarya. Rustandi, R. (2018). Analisis Wacana Kritis Komodifikasi Daí dalam Program Televisi, Communicatus: Jurnal Ilmu Komunikasi, 2(2), 197-222. DOI: https://doi.org/10.15575/cjik.v2i2.4949.

Rustandi, R. (2019). Cyberdakwah: Internet sebagai Media Baru dalam Sistem Komunikasi Dakwah Islam, Nalar: Jurnal Peradaban dan Pemikiran Islam, 3(2), 84-95. DOI: 10.23971/njppi.v3i2.1678.

Rustandi, R. (2020). Dakwah Komunitas di Pedesaan dalam Perspektif Psikologi Komunikasi, Irsyad: Jurnal Bimbingan, Penyuluhan, Konseling dan Psikoterapi Islam, 8(3).

Sambas, S. (2009). Konsep dakwah menurut pemikiran Muhammad Abduh dalam Tafsir Al-Manar. Bandung: RajaGrafindo Persada.

Saputera, A. R. A., \& Putra, M. Y. (2020). Tinjauan Hukum Islam Terhadap Problematika Investasi Haji Pada Masa Pandemi Virus Covid-19, ElAbli: Jurnal Hukum Keluarga Islam, 1(2), 1-19. https://jurnal.stainmadina.ac.id/index.php/el-ahli/article/view/164.

Soekanto, S. (2014). Memperkenalkan Sosiologi. Jakarta: Penerbit: CV. 
Rajawali.

Yanti, Y. C. M. (2019). Psikologi Komunikasi Dalam Meningkatkan Dakwah Da'i Di Masjid Fajar Ikhlas Kelurahan Sumberejo Kecamatan Kemiling, Al-Adyan, 14(1), 245-263. DOI: https://doi.org/10.24042/ajsla.v12i2.2112. 
